\title{
A Study on the Relationship Between New Business Start Up and Micro Credit Institution and Business Growth of Small Scale Enterprises
}

\author{
Alabi F. A. \\ Department of Business Administration, Bowen University, Iwo, Nigeria \\ E-mail: falabious@yahoo.com
}

Received: March 1, 2019 Accepted: April 1, 2019 Published: June 30, 2019

doi:10.5296/bms.v10i1.14533ＵRL: https://doi.org/10.5296/bms.v10i1.14533

\begin{abstract}
This academic study evaluates the evaluate the relationship between new business start up and micro credit institution and business growth of small scale enterprises that operates in six states that made up the South-west geopolitical zone of Nigeria. The study, which is based on descriptive research methodology, involved the use of data from both primary and secondary sources. The stratified sampling technique was used for determining the sample population, while well structured questionnaires was used as the main tool for collection of primary data. The Microfinance Bank records of clients served as the main source of secondary data for this study. Both the descriptive and inferential analytical techniques of the SPSS packaged were used to analyze the data obtained from the respondents. The results indicated significant relationship between new business start-ups and business growth of Small Scale Enterprises (SSEs). The findings also revealed that increasing the start-up capital will increase the chances of business survival and growth. Consequently, we recommend that the federal, state and local government should create lending programs that will enable aspiring entrepreneurs to have more access to microcredit. We also suggest that Nigerian government should enact laws and implement policies that will make it easier for small scale entrepreneurs to obtain finance necessary for the expansion of their businesses.
\end{abstract}

Keywords: Business startups, Small scale enterprise, Business growth, Microcredit institution 


\section{Introduction}

\subsection{Background to the Study}

More than 500 million of the world's populations are known to live below the poverty line (Akingunola Adekunle, Adegbesan and Aninkan, 2013). However, this segment of the world population is actively involved in economic activities. Even without access to primary health care, good shelter, food and other necessities of life, the poor people engage in economic activities as micro entrepreneurs, with some employed in microenterprises. Through this way, they were able to earn some income. Akingunola et al (2013) observe that in Nigeria, these micro entrepreneurs offer varieties of goods in small workshops; partake in retail activities and basic trading; engage in making of furniture, pans and pot or sell vegetables and fruits. Even though these basic activities are essential for the economic growth of any nation, the major players in these sub-sectors have no access to loans, adequate financial services and safe places for their savings (Egwuatu, 2008). The poor in developing countries like Nigeria, generally lack access to bank loans, pension funds and insurance. Those that are in need of financial assistance obtained help from credits from informal money-lenders and community saving groups, many of whom give out loans at exorbitant interest rates that could not be afford by majority of local entrepreneurs. Furthermore, the existence of these informal financial providers is a clear indication of the lack of a formal market.

Unfortunately, the inability of micro entrepreneurs to access badly needed loans can have potentially negative effects on their business performance. Perhaps, this is one of the major reasons why many of them continue to patronize the informal sectors, despite the high interest rate. Thus, mobilization of savings at community level remains an essential element for the development of the community all over the world. These traditional schemes enable poor individuals to obtain loans from moneylenders and community savings, and consequently mobilize local resources through concerted action(s) (Egwuatu, 2008). But there have been widespread concerns on whether the funds from these informal bodies are enough to assist aspiring entrepreneurs to establish, sustain and grow their enterprises.

The problems of micro entrepreneurs are further compounded by the unwillingness of the conventional commercial banks to assist them. In fact, it is extremely rare to hear of situation, where these banks offer loans and other financial services to small business. Akingunola et al (2013) attributed this practice to the generally held belief that medium and large enterprises are more creditworthy. Thus, commercial banks rarely do business with micro enterprise, which they perceived as having high cost and risk, in regard to credit granting. Nevertheless, this huge challenge has not prevented the emergence of startups, as many micro enterprises continue to spring up, even without the huge financial support of the commercial banks, which ordinarily should be responsible for the provision of basic financial services to the society.

The difficult situation of the micro enterprises prompted the Nigerian government in 1990, to enact relevant legislation that eventually paved way for the establishment of the community 
banks. The primary objective behind this decision is to minimize the financial constraints of micro enterprises and also empowered the poor, who has the dream of establishing their own business. Additionally, the government hopes that the establishment of the community banks may also minimize unemployment, narrow the economic gap between rural and urban areas, eliminate poverty and trigger economic growth of the country. But Akinboyo (2007) pointed out that a successful accomplishment of the above stated objectives will require massive capital infusion, which will help ensure that businesses in both the urban and rural areas obtained enough money for operations. Nonetheless, the micro finance banks have considerable roles to play in the quest to achieve these objectives.

Fortunately, various governments of the developing nations, Nigeria inclusive, are increasingly recognizing the huge contribution of the microfinance banks in the development and subsequent facilitation of entrepreneurship. In these countries, micro credit institutions act as the fundamental engines for promotion of economic growth. Using the resources provided by these institutions together with their innovative ideas, micro entrepreneurs add value to the economic growth of the society, through creation of new jobs, commercialization of new products and establishment of new firms. This is actually a positive trend, as studies by many authors revealed that high level of entrepreneurial activity is essential for economic development of any nations (Akinboyo, 2007; Hisrich, Peter and Shepherd 2008; Muogbo and Tomola, 2018). This is because; entrepreneurs serve as the link between new ideas and economic development.

It is quite interesting to note that many scholars and researchers are exhibiting great interest in studying the crucial roles of entrepreneurship in the economic development of nations. One of such authors, Aderibigbe (2013), described entrepreneurial development as individuals' expression of new opinions; disposition to accept and try out new methods; exhibition of greater concern for organization, efficiency and planning, having better sense of punctuality and believing in distributive justice. Additionally, Hisrich et al. (2008) observe that entrepreneurship is a concept that encourages both men and women to exhibit more interest in the present and future, than the past. Both Aderibigbe (2013) and Hisrich et al. (2008) admit that entrepreneurship could not emerge as a successful tool for economic development without the full participation of micro credit institutions.

Moreover, Simanowitz and Brody (2004) pointed out that the micro credits from microfinance banks are very essential for a successful accomplishment of the Millennium Development Goals. This postulation is partly attributed to the fact that such institutions are capable of mobilizing rural savings. Furthermore, most micro credit institutions have their roots on local culture, which make their modus of operation clearer to members of the public. Thus, they remain at the best position to provide loans to local small enterprises that lack access to the credit facilities, deposits and financial services, which ought to have been provided by the formal financial institutions. Indeed, some scholars like Ndife (2013) have observed that the financial services of the formal banking institutions are not really suitable for micro enterprises. Apart from the inability of these small enterprises to offer required 
collateral security, the cost of owing business with the small business are quite too high, when considering the small amount of loans they usually requested for. Furthermore, the cost of recovering those loan is also too much. Thus, for the bigger financial institutions, it is quite risky doing business with these micro and small enterprises. Unarguably, such perceived risk may even be higher for start-ups that intend operating in that sector.

In Nigeria, all stakeholders have recognized micro credit as tool that is very essential for a successful promotion of micro and small enterprise. According to Ndife (2013), this conviction is partly base on the fact that more than 70 percent of the country's population is directly or indirectly involved in this sector. Fortunately, the country's government at all levels has also recognized micro credit as a very indispensable tool for financial empowerment of the people, which incidentally is also necessary for sustainable growth and development (Olaitan, 2006). As already pointed out, micro and small enterprises are generally considered not credit worthy by the conventional banking institutions. But substituting the roles of the conventional banking institutions with the micro credit institutions is obviously one of the most reliable ways to boost the development as well as growth of the micro and small enterprises.

From the discussion so far, it is crystal clear that credit institutions have the potential to become the primary source of funding for the micro and small businesses. In Nigeria, this is already the case, as the micro financial institutions have empowered millions of households that could not access the classical financial services. Akingunola et al (2013) observed that many of these individuals have been able to start up their own businesses and consequently become full participants in the country's economic activities. The fact that entrepreneurship is a very powerful tool for facilitation of economic development and growth in the developing countries is a clear indication that the micro credit institutions are instrument of development in the poor countries. What this implies is that they are naturally involved in the eradication of poverty, creation of jobs, empowerment of the masses, innovations and other relevant effects. This explains why many developing countries, Nigeria inclusive, have become more proactive in the promotion of entrepreneurship through the microfinance banks.

Naturally, the poor masses have huge potential for entrepreneurship. Thus, Iweala (2005) is of the opinion that this potential can be enhance substantially through the provision of microfinance services. In other words, the provision of relevant financial services and support can help the poor masses to establish their start-ups successfully, thereby becoming more engaged in economic activities. This postulation is fully supported by Fashola (2008), who asserted that micro credits have the capacity to take off unemployed graduates from the streets. This is because, rather than searching for nonexistent jobs, these gradates can easily acquires resources that will enable them to start their own business, become employers of labours and consequently generate wealth for themselves, their family members and even the country as a whole. Niekerk (2008) opines that is quite impossible to achieve such tremendous economic growth, without formulating a well structured framework that could meaningfully support economic activities at the grass root level. 
The discussion so far indicates that micro credit is essential for economic development of a nation, including the establishment and consequent growth of start-ups. In other words, it is a sort of liberating force that ought to be fully applied in all aspect of economic activities, starting from the institutionalization of start-ups to their development and growth. Thus, it has become essential to carry out a study that specifically evaluates the roles of micro finances on new business start-ups. It is against this backdrop that this study strived to evaluate the relationship between new business start up and micro credit institution and business growth of small scale enterprises.

\subsection{Statement of Problem}

It is an indisputable fact that microfinance institutions are instrument of economic development, especially in poor countries. As already pointed out, the poor masses have huge potential for entrepreneurship. These people have innovative ideas for both their existing and planned businesses. Unfortunately, most of them lack the financial resources necessary for a successful implementation of such ideas. This lack of finance has dire negative consequences on the economic activities of the countries, which will in turn lead to increase in unemployment, poverty and poor standard of living. Thus, it is important for the microfinance institutions to expand their operations to include financing of start-ups. In other words, these institutions have to provide solutions to the financial constraints of both existing and aspiring entrepreneurs, so that they will be able to contribute a productive part of the society to make it sustainable (Oshitola, 2012).

It is important to note that in addition to financial constraints, there are actually several problems that beset entrepreneurship development and start-ups in developing countries. The manifestation of these problems can vary from one country to another. However, there are some features that are quite common to all countries and these include: high cost business operation; complex bureaucratic procedures in setting-up a business; asymmetric information regarding the existing business climate, lack of financial assistance, inadequate capital for production investment and undeveloped infrastructural facilities for entrepreneurship and start-ups. Perhaps, the most prominent of the above stated challenges is the inability to obtain financial assistance for entrepreneurship development and start-ups. According to Aderibigbe (2001), microcredit institutions are already aware of the various challenges that are confronting entrepreneurship development and start-ups, and are already trying to proffer suitable solutions for the issues. Thus, this research works strive to evaluate the relationship between new business start up and micro credit institution and business growth of small scale enterprises.

\subsection{Research Objectives and Hypothesis}

The primary objective of this academic study is to conduct a critical evaluation of the relationship between new business start up and micro credit institution and business growth of small scale enterprises. The dependent variable for this study is the small scale enterprises growth (SSEs), while the success of business start-ups is independent variable. In order to 
achieve the stated objective of this academic study, the following research question was generated;

i. What is the relationship between new business start up and micro credit institution and business growth of small scale enterprises?

The research hypothesis is deduced from the research question as follows:

$\mathrm{H}_{0}$ : There is no significant relationship between new business start up and business growth of Small Scale Enterprises (SSEs) in South Western Nigeria.

\section{Literature Review}

\subsection{The Conceptual meaning of Microfinance Bank}

According to the Central Bank of Nigeria, Microfinance Banks are firms that have the license to offer micro finance services such as; domestic loans, savings, transfer as well as every other financial services that may be required by entrepreneurs and economically active poor to set up and operate a business. This definition indicates that microfinance banks are primarily involved in the provision of services that will help empower people; minimize poverty; ensure creation of job; ensure generation of income and promote entrepreneurial skills. In other words, microfinance bank as an institution is solely concerned with delivery of financial services to the poor and low-income earners, who are actually self employed.

Muogbo and Tomola (2018) noted that about twenty years ago, the term was simply used in reference to the provision of microcredit (very small loan), to poor members of the society, so as to enable them to expand their existing business and/or engage in new business venture. But the authors observe that in recent years, the conceptual meaning of the term has been expanded to include an institution that does not only provide microcredit, but also deliver other allied services like money transfer, insurance, savings opportunities, and credit. According to Muogbo and Tomola (2018), this new trend is attributable to the fact that these poor people, who lack access to the conventional formal banking system, are also in need of varieties of financial products. They also observed that such financial products are actually essential in their quest to achieve meaningful improvement of the existing business operations.

The definitions so far indicate that the microfinance banks are companies that specialize in the delivery of financial services to the poor. This postulation is also supported by Ogunleye (2015), who opines that microfinance deals mainly with the provision of financial services to poor members of the public, whom because of their socio-economic status, are not covered by the normal banking system. Ogunleye (2015) listed three features that differentiate microfinance bank from the formal financial institutions as follows:

i. The low volume of collected savings and loans,

ii. No requirement for asset-based collateral, and 
iii. Provision of basic banking services.

\subsection{Challenges of Micro Financing in Nigeria}

In the previous section, it was stated that the legal and functional specifications of microfinance banks according to the $\mathrm{CBN}$ have to do with provision of financial services to economically poor members of the society. In their study, Muogbo and Tomola (2018) identified five major policy objectives of micro credit institutions that operate in Nigeria as follows:

i. Meaningful contribution to rural development and transformation

ii. Promotion of linkage programs between universal/ development banks, micro finance banks and specialized institutions.

iii. Facilitation of delivery of microcredit services to micro, small and medium entrepreneurs.

iv. Project the informal sectors toward national financial system.

v. Increase accessibility of financial service to more Nigerians that are economically active and productive.

In order to ensure sustainability, Nigerian-based microfinance banks have devised some strategies that are specially aimed at ensuring a successful delivery of services to members of the public. Nevertheless, there are still a number of challenges that currently militate against the institutions' quest to operate optimally. Muogbo and Tomola (2018) identified some of these challenges as follows:

The issue of repayment: One of the main challenges confronting microfinance banks is the issue of loan repayment default. Ojo (2013) observes that this problem, which can be likened to a deadly virus afflicting the sector, is very much capable of demoralizing staffs of microcredit institution. Furthermore, the author also pointed out that the problem of loan repayment default can deprives beneficiaries of valuable services. Nevertheless, Muogbo and Tomola (2018) argue that in some cases, the problem can actually be a symptom of poor leadership.

Inadequate re-financing facilities: Some Nigerian-based micro finance banks are not profit oriented. Consequently, such non- profit status limit their ability to engage effectively with other financial institutions like the commercial banks.

The risk of client apathy and drop-out: Microfinance banks are also at greater risk of experiencing client's drop-out and apathy. Muogbo and Tomola (2018) blamed this on inappropriate delivery strategies and customer services.

The struggle for internal control challenge: Some micro finance banks adopt informal approach in their operations. Unfortunately, such techniques, together with large transactions can result to serious internal control challenge. Muogbo and Tomola (2018) observe that 
when such problem is encountered, there is a great risk of breaching operational process at the collection and disbursement points.

Lack of adequate experienced credit staff: Currently, the functional roles of micro finance banks are not just restricted to loan dispensation. This means that experienced and skilled personnel are required, in order to ensure optimal performance of the institution. Unfortunately, many micro credit institutions do not have experienced credit staff. These problems are the major reasons why many of the institutions perform poorly in area of planning, development of new product and effective management of clients. Majority of credit staff of microcredit institutions lack experience, which in turn limits the firm's expansion and institutional performance.

High operational cost: Lastly, the operational costs of microfinance banks are quite high. Most times, this problem is inevitable as the companies have to deal with several loan applications; collect repayment dues from several locations, especially in rural areas and also process, manager and monitor large numbers of accounts.

\subsection{Microfinance Models}

There are several operational models that can be used to describe current microfinance. However, the two most common microfinance models are Grameen model and Non-Government Organization (NGO) Model

\subsubsection{The Grameen Models}

This model is based on the operational method of the Bangladeshi's Grameen Bank, which was established as an independent specialist bank in 1983. Its primary objective is to provide credit services to poor Bangladeshis that reside in the rural areas. In other words, the program originally targeted landless people, who ordinarily cannot obtain loans from the normal banking institutions. Thus, the concept of the Grameen model is based exclusively on the concept-informal lending to the poor.

According to Akinboyo (2007), the Bangladeshi's Grameen Bank like most Nigerian Microcredit institutions, was created with the main purpose of improving the economic situations of the rural poor. Like microfinance banks, Grameen Bank strived to accomplish this important objective by creating more opportunities for self-employment of the people. Poor Bangladeshis were able to obtain loan without any physical collateral, which couldn't have been possible with commercial banks. Instead, the loans obtained in this case were secured by group collateral, which is also complemented with peer monitoring and pressure. Through this way, repayment of the loan is accomplished.

In the Grameen's model, disbursement of loans was accomplished through banking units. Each unit consists of five individuals that requested for the loan. Every member of the group obtains loan, but the entire group is responsible for the repayment. But in the first round, the loan is given to just two members of the units. The next two members will obtain their own loans, if the first two were able to repay their loans. This second payment is issued just four 
to six weeks, after repayment of the first loans. The remaining member will also able to obtain his or her own loans, once the two previous members have repaid their loans. In this arrangement, the repayment of loans facilitates the next disbursement. The cycle will continue as long as there is no default in repayment. Thus, once there is an incident of default, the remaining members of the group won't be entitled to further disbursement of loans. About six to eight groups of these banking units made up a community known as the centre, which is managed by a single Bank official.

The modality of the Grameen Model's operation is based exclusively on collective guarantees, peer pressure from members of the same units and close supervision. Consequently, the model was quite successful as a bank of the poor. Furthermore, its social movement is based mainly on the principles of training and awareness, which in turn help to promote active participation of poor members of the society.

\subsubsection{Non-Government Organization (NGO) Model}

Another popular operational model is the Non-Government Organization (NGO) model. It is actually an informal model that is largely based on the Grameen Model. However, unlike the Grameen Model, the NGO model is both sector ally motivated and gender specific. For instance, there are trader union, farmer union, women group in this organization. Today, there are many NGOs with different names. But almost all of them have some basic features of the Grameen banks. In Nigeria, one notable example is the Left Above Poverty (LAPO), which operate just like the Grameen Bank and also focus on provision of credit facilities for the poor. But Muogbo and Tomola (2018) observe that in Gambia and Ghana, the most successful examples of micro credit programs with the above stated features are the Women finance association. According to the authors, the rate of repayment among these groups is considerably high.

\subsection{Theoretical Framework}

This academic research is based on the transaction cost theory, which was first proposed by Coase (1960). According to this theory's postulations, before the execution of any market transaction, it is very essential to first determine who exactly to deal with, carry out some negotiations, draw up the contract and then conduct preliminary inspection in order to ensure absolute observance of the terms of contract. In their study, Bhatt and Shui-Yan (1998) conceptualized the theory as a non financial cost, which the lender and borrower may incurred before, during and after the disbursement of loans. Examples of costs that may be incurred by the lenders include: cost of assessing feasibility of the project, cost of sourcing for the fund required for the loan disbursement, cost of screening the huge volume of loan applications, cost of screening potential borrowers, cost of designing credit contracts, cost of providing credit training to borrowers and staffs and cost of providing credit training for both borrowers and staff. On the other hands, some examples of costs that may be incurred by the borrowers include: cost of group formation, cost of filling paper work, cost of conducting negotiation with the lender, cost of dealing with the required paper work, costs of attending 
meetings, cost of time spend on project appraisal and transportation costs. The main determinants of the transaction cost rate are those parties involved in a particular project. According to Stiglitz (1990), both parties are solely responsible for minimizing any risk confronting the entire transaction process.

Transaction costs can also be potentially used as a unit of analysis. A study by Williamson (1985) led to the identification of six important points why transaction costs can be used for accomplishing such objectives. These include:

i. the microanalytic nature of the transaction costs;

ii. opportunistic and bounded rationality behaviors are fully considered by transaction costs analysis;

iii. the introduction and subsequent development of the economic importance of specification assets;

iv. reliance on comparative institutional analysis;

v. recognition of business as more of 'government' rather than the production function;

vi. depending more on the ex post agency contract.

In regard to the processing of credit, transaction costs are generally considered as those costs which are incurred by both the borrower and the lender, in course of the process. Base on this context, De Guia-Abiad (1991) cited in Masuko and Marafuru (2003) defines transaction costs acquired in course of loan processing as those noninterest burden, which are incurred by the lender. According to the authors, such costs are specifically encountered during the evaluation, distribution, approval and collection of loans as well as consequent repayment of the loan.

Hosseini et al. (2012) identified some specific components of transaction costs on the borrower side as follow: cost of applying for borrowing; security costs; cost of controlling and monitoring; cost of establish a guarantee; opportunity cost, travel cost, cost of preparing relevant documents etc. Sulistya and Darwanto (2016) identified high transaction cost as one of the major challenges that militate against entrepreneurs' quest to access financial loans from banks. Thus, the authors recommend group lending scheme as the most effective strategy for minimizing the transaction costs. According to the authors, such approach will help to make sure that both sides pay lower transaction costs. Through this way, the welfare of small scale enterprises can be improved considerably.

\subsection{The impact of microcredit accessibility on business growth of small scale enterprises}

Generally, the term microcredit refers to small loans. But when such small loans are supplemented with other financial services like insurance, payment services, savings, pension and insurance; the term become known as microfinance. Thus, microcredit, as rightly pointed out by Mohammed and Mohammed (2007), is an element of microfinance. Nevertheless, both microcredit and microfinance are primarily aimed at providing credit to poor members, who are economically active and operate small scale enterprises. However, the transaction 
cost of the loan disbursement process involving microcredit institution is relatively high (Stiglitz, 1990).

Before we proceed with the empirical studies on the relationship between microcredit access and business growth of small scale enterprises, it is imperative to provide some explanations on the risks pose by high transaction costs. Microcredit is mainly concerned with reaching out to the poor masses. But Stiglitz, (1990) observes that in the course of fulfilling this important objective, the cost of outreach increases considerably. This is partly because of the costliness of providing financial services to the poor. Moreover, it is quite impossible to make the micro credit institution to become more sustainable, without the necessary strategies for avoiding risks and excessive costs. In fact, Hulme and Mosley (1996) notes that without accurate break-even interest rates, it will be extremely difficult for microcredit institution to sustain its operations. What this implies is that the interest rate ought to be higher, so as to make sure the revenue covers the operational costs and every other expenditures. Achieving this objective is quite challenging, as micro credit institutions are required to subsidise their interest rates. The responsibility of minimizing such risks remains solely that of the companies. There are concerns among some scholars that in the quest to achieve this objective, the microcredit institution may not be able to have considerable impacts on the growth of the small enterprises.

Generally, small scale enterprises usually request loans that are smaller than those demanded by bigger corporations. However, the interest rates of the two categories of firms remain basically the same. This is a clear indication that per unit cost is quite high for the microcredit institutions, as they usually deal with customers that need smaller loans and operate small savings accounts (Robinson, 2003). The relative high rates of the loans do not discourage small scale enterprise from repaying their debt, and still applying for new loans. Rosenberg (1996) attributed this to the fact that small scale business operators enjoy greater social benefits that surpass the high interest rate. He also observe that this high interest is one of the techniques, which microcredit institutions employed in order to deal with the persisting issues of adverse selection. Moreover, the author also observes that the small scale entrepreneurs remain undaunted, as most of them that participated in the study prefer convenience to returns.

As already pointed out, microcredit institutions are primarily concerned with narrowing the gap created by remoteness, illiteracy, gender and poverty. But in order to achieve this important objective successfully, it is also necessary to train these small scale business operators, so as to ensure they have the right skills required for effective business management and productions. In addition to enabling them have better access to markets, such training will also help the clients to make more profitable use of the loans that are given to them. In the words of Ledgerwood (199), these training are very essential for optimal performance of small scale business, as effective financial services to the poor requires social intermediation.

A number of studies have also revealed the huge potential of small loans in poverty 
alleviation (Khan and Rahaman, 2007; Wehrell, Campbell, Cunningham and Lee, 2002; Robinson, 2001; Otero, 1999). The findings of these authors are in line with the postulation of the UNCDF (2009), which states that microcredit is a very powerful tool that can be used by small scale entrepreneurs to expand their economic opportunities and consequently minimize the vulnerabilities of the poor. In their study, Asiama and Osei (2007) observe that the above benefits are possible, as microcredit enables small scale business owners to meet their primary business needs. Arguing from a sociological perspective, Khan and Rahaman (2007) affirm that increased accessibility of credit services enable owners of small scale enterprises to obtain productive capital, which according to them, can boost the entrepreneurs' confidence and consequently motivate more people to participate more in the rural economy. Pronyk, Hargreaves and Murdoch (2007) argue that microcredit can have positive immediate and long term consequences, since they are capable of boosting poor people's ability to access health services, obtain education, shelter and food, as well as boost their volume of income generation.

Microfinance has also been identified as one notable way of increasing women's participation in economic activities. This postulation is the main position of most gender activists. For instance, Boyle (2009) argues the microcredit is a reliable tool for increasing optimal performance of women-run enterprise. The author added that through such technique, women participation in economic activities is increased considerably, which in turn enhances their household wellbeing. Similarly, Littlefield (2005) opines that microcredit gives young entrepreneurs the opportunity to establish and grow their own businesses. The authors observe that such effect is more prominent among young females and that is also improves their overall well-being as well as their ability to feed and educate their household. This postulation is also observed by Karlan and Zinman (2006) in their study, which revealed that South African-based entrepreneurs that obtained microcredit services are better off than those that never benefitted from such services.

Khan and Rahaman (2007) carried out an empirical study on the impact of microfinance on recipients' ability to establish and grow their business. The findings showed that in addition to boosting poor people's ability to participate more in economic activities, microcredit services also enhances their livelihood, which has the potential of moving them out of poverty. Perhaps, the most prominent finding of this study was the confirmation that microcredit services remain a formidable tool of empowerment. What this implies is that, it can enhance poor people's ability to establish and grow their own businesses. In another study, Priya (2006) used regression model to evaluate the effects of microcredit on the recipients' ability to establish and grow their business. The findings showed that increased accessibility of microcredit correlate strongly to business growth. Additionally, the author discovered that active participation in microcredit services enable existing business owners to grow their income yield by $10 \%$.

However, a number of studies have indicated that even though microcredit is quite effective in minimizing microcredit, it is not always the solutions to some of the issue confronting 
small scale business owners (UNCDF, 2009; Hashemi and Rosenberg, 2006; Buckley, 1997; Rogaly, 1996). According to these study, microfinance is just but one of the numerous tools that can be used to reduce incidents of poverty in the society. Even scholars like Buckley (1997) and Rogaly (1996) argue that under certain conditions, microfinance may not be suitable for empowering very poor members of the society. This inference is also in line with that of Rosenberg (2006) who, noted that the poorest members of the society may not benefit from microcredit services.

In another publication, Roodman (2009) affirms that microcredit has the potential to leave beneficiaries worse than they have ever been. His statement is based on the fact that microcredit is similar to mortgage and credit cards, which have made some people poorer in the advanced countries. He notes that the benefits of microfinance tend to be exaggerated. Thus, he argues that even though the promise of microcredit is irresistible, its positive effects on the economy remain largely elusive as the objective of reducing poverty is never accomplished in most cases. Similarly, Karnani (2007) in his study is also sceptical of microfinance programs, as he noted that even though most of them produce some non-economic benefits, there is no considerable alleviation of poverty. Karmani (2007) listed the most effective tools for poverty alleviation to include creation of more jobs and improving employees' productivity, but not through delivery of microcredit services. According to him, poor people that obtained loan hardly invest such resources on hiring of labour, fixed capital and new technology.

Nevertheless, adequate finance remains essential for the establishment and development of small scale enterprises as well as economic growth of the society. For instance, Claessens and Tzioumis (2006) identified lack of finance as a major factor responsible for the persistence of economic inequality in the society. The availability of finance increased not just the individual's employment opportunities, but also the ability to establish and grow micro, small and even medium enterprises. All these will ultimately led to a complementary increment of the populace's income and asset. Thus, even though microfinance may not be suitable under every situation, it still remains a tool of economic empowerment. Sachs (2009) observes that in order to obtain the best result in regard to microcredit, the relevant stakeholders should avoid the implementation of one size fits all strategy. According to the author, the dispersed population in certain rural areas, coupled with poor governance infrastructure, can possibly limit the benefits of microfinance in Africa. Under such situation, the introduction of training programmes, grants and improvement of the existing infrastructures becomes the most effective way to empower the poor.

A number of authors have also carried out empirical studies that are specifically aimed at determining whether the microcredit is having any effects on the various problems that confront entrepreneurship. In one of such studies, Buckley (1997) concentrated on micro enterprises that operate in three African countries namely; Ghana, Malawi and Kenya. His findings did not reveal any substantial progress among micro enterprises that operate in the three countries. According to him, this unexpected result is due to the fact that injection of 
capital is not the main issue confronting the sector, but lack of infrastructural development. Using a matching strategy, Chemin (2008) investigate the effect of microcredit on Bangladesh. The findings indicated that microcredit actually has positive effects on school enrolment and expenditure per capita. However, the author admitted that the effect is considerably lower than what was expected prior to the study. In another empirical study, Aguilar (2006) investigated the impact of microfinance on farmers that operate in rural areas of Malawi. The finding revealed no considerable positive effect of the microcredit. In the words of the researcher, those farmers that obtained small loans were no better off that those that did not obtain any loan. Like Buckley (1997), Aguilar (2006) argues that more efforts should be channelled toward provision of relevant trainings. This postulation is also supported by Ausburg (2008), who opines that microcredit cannot be successfully without the introduction of the plus components. In this context, plus component refers to training in market development, managerial skills and financial management. In conclusion, it is quite evident that the various stated benefits of microfinance are not always being accomplished. Its success is determined to a considerable extent by functional arrangement, microfinance structure and client characteristics. What this implies is that the exact effect of microfinance is context specific.

\section{The Research Methods}

This study is based exclusively on the descriptive research method. It is the most suitable methodological approach as it prevents the researcher from having control over the concomitant variables, which has already been manipulated. The stratified sample technique was used by the researcher to determine the sample population for the study. This is very important, as it allows the researcher to provide suitable answers to the research questions, thereby achieving the stated research objectives.

The population of study consists of the small scale entrepreneurs that operate in South-West geopolitical zone of the country. However, the stratified sample technique was used to divide this population of study homogenous discrete units known as the strata. This method was employed so as to make sure all the respondents have equal chance of being selected for the survey. Furthermore, the use of stratified sampling technique helps the researcher to eliminate errors and biasness, and also make sure the measurement becomes more manageable and appropriate for future research.

This academic research involved a combination of primary and secondary data. The main tool for collection of primary data in this study is well-structured questionnaires. These are administered to owners of SSEs. In other words, the questionnaire was utilized to obtain necessary information on microcredit and small business start-ups as well as its growth and performance. Additionally, the researcher also used semi-structured interviews to obtain data regarding the practice of microfinance among banks that operate in the area of study. The respondents that are subjected to this interview are Senior Bank officials. Before its eventual administration, the researcher tested the psychometric property of the questionnaire. The essence is to eliminate ambiguous items and ensure the suitability of the scale. The 
questionnaire consisted of six different sub-sections.

The researcher also utilized secondary data that was obtained and extracted from SMEDAN studies. Some secondary information was also obtained through a comprehensive review of related literature. Furthermore, the researcher adopted a 2012 SMEDAN report on SSEs and consequently drawn a purposive sample from the population that consist of about seven thousand, six hundred and ninety (7690) participants. After this, a convenience sampling method was used to obtain the actual sample population of five hundred and sixty participants (560). The sampling process employed in this study, helped the researcher to obtain a sample population that is a true representation of the entire population across the South-West geopolitical zone of the country. This milestone was accomplished successfully, due to the fact that the entire population of study was actually split into discrete units known as strata, prior to the distribution of the questionnaire. The strata are the states in South West (Oyo, Osun, Ogun, Ondo, Ekiti and Lagos), where the Microfinance Banks and their clients/customers operates. All the respondents that participated in the study have benefited from both the financial and non-financial products offered by these microcredit institutions for more than five years.

The distribution of questionnaires and conduction of the interview were both done manually. The researcher approached all respondents and obtained their consents before proceeding with the survey proper. Each of the participants were duly informed of the major objectives of the exercise and consequently requested to be more objective in the response. The responses obtained from the responses were then analyzed statistically. The researcher specifically used both the descriptive and inferential analytical techniques of the Statistical Package for Social Sciences (SPSS version 22) to analyze the data obtained from the survey. Additionally, tables and Bar-Chart graph were used in the descriptive analysis study while Pearson Product Moment Correlation Coefficient (PPMC) analysis were used to test the stated hypotheses at 0.05 level of significant.

\section{Findings}

Table 1. Frequency Distribution of Questionnaires Returned from South Western States:

\begin{tabular}{cccc}
\hline S/no & State & Frequency (f) & Percentage (\%) \\
\hline 1 & Ekiti & 80 & 15.4 \\
\hline 2 & Lagos & 100 & 19.2 \\
\hline 3 & Ogun & 80 & 15.4 \\
\hline 4 & Ondo & 80 & 15.4 \\
\hline 5 & Osun & 80 & 15.4 \\
\hline 6 & Oyo & 100 & 19.2 \\
\hline & Total & 520 & 100 \\
\hline
\end{tabular}

Source: Field Survey, 2016.

Table 2. Frequency Distribution of Respondents By Business Age 


\begin{tabular}{lll}
\hline Age of Business & Frequency $(\mathrm{f})$ & Percentage $(\%)$ \\
\hline 1-5 years & 223 & 42.9 \\
\hline 6-10 years & 157 & 30.2 \\
\hline 11-20 years & 80 & 15.4 \\
\hline 21-30 years & 38 & 7.3 \\
\hline 31-50 years & 16 & 3.1 \\
\hline 50 years and above & 6 & 1.2 \\
\hline Total & 520 & 100.0 \\
\hline
\end{tabular}

Table 3. Frequency Distribution of Respondents who obtained Loans

\begin{tabular}{lll}
\hline Loan from any micro credit institutions & Frequency (f) & Percentage (\%) \\
\hline Yes & 389 & 74.8 \\
\hline No & 131 & 25.2 \\
\hline Total & 520 & 100 \\
\hline
\end{tabular}

\section{Testing of Hypotheses}

This section reports the results of the null hypotheses tested in this study in order to draw salient inferences and conclusions.

$\mathrm{HO}_{1}$ : There is no significant relationship between new business start up and business growth of Small Scale Enterprises (SSEs) in South Western Nigeria.

Table 4 reveals that there is a significant relationship between new business start up and business growth of small scale enterprises (SSEs). The r-value (518) $=.829 * *, p<0.05$ ). Hence the null hypothesis is rejected. The table further reveals that new business start up had positive relationship and an impact on business growth of Small Scale Enterprises (SSEs) in South Western Nigeria. This implies an increase in new business startup capital (infrastructure, electricity and low interest rate of loan etc) will increase the survival for business growth of small scale enterprises (SSEs). Coefficient of determination $\left(r^{2}=0.4744\right)$ reveals that new business start up had a low effect on business growth, that is it accounts for $47 \%$ variance in business growth of Small Scale Enterprises (SSEs) in South Western Nigeria.

Table 4. PPMC showing the relationship between new business start up and micro credit institution of business growth of (SSEs) in South Western Nigeria.

\begin{tabular}{|c|c|c|c|c|c|c|c|}
\hline Variable & $\mathrm{N}$ & Mean & Std-Dev & df & r-value & $\mathrm{P}$ & Remark \\
\hline New business start up & 520 & 57.15 & 16.491 & & & & Hoз rejected \\
\hline Business growth of SSEs & 520 & 60.437 & 18.1539 & 518 & $.829^{* *}$ & $<0.05$ & \\
\hline
\end{tabular}


**. Correlation is significant at the 0.01 level (2-tailed).

\section{Discussion of Findings}

The Hypothesis state that: there is no significant relationship between new business start up and business growth of Small Scale Enterprises (SSEs) in South Western Nigeria. The results of the statistical analysis revealed a substantial relationship between new business start up and growth of SSEs. This finding is in line with similar studies. For instance, it has been observed that strategy development (Julien and Ramangalahy, 2003) and organizational learning (Chaston et al, 2001) enhance the competitiveness of business firms. In another study, Sadler-Smith et al (2003) observed that the performance of small businesses correlate positively with a homogeneous collection of organizational capabilities. In that same study, it was also observed that even heterogeneous set of practices also correlate positively with performance of SSEs. Adizes (1979) observes that the leadership style and attitude of the organization management is also crucial for the success of a business organization. The author specifically observes that when such attitude and leadership style are future oriented, the chances of business success will be considerably high.

Innovation, dynamism and flexibility have also been identified as being crucial for the success of every business organization. Thus, it is imperative for new startups to always integrate elements of creativity, innovation and flexibility into their normal business operation. According to Arbaurgh and Sexton (1996), the failure of startups to employ this approach is one of the major reasons why newly established business failed to grow into multinational corporations. It is imperative to note that there is no single strategy for business growth (Chaston and Mangles, 1997). Thus, startups can boost their chances of succeeding by avoiding excessive concentration on single-strategy transformation initiatives, which explains the need for innovations and creativity.

\section{Conclusion}

As already pointed out at the beginning of this academic research, the primary objective of this academic study is to evaluate the relationship between new business start up and micro credit institution and business growth of small scale enterprises that operates in the South-West geopolitical zone of Nigeria. The result of the study indicates that new business start up correlate strongly with business growth of SSEs. Furthermore, the statistical analysis indicated that new business start up had positive relationship and an impact on business growth of SSEs in the region. The implications is that any increase in new business start-up capital such as low interest rate of loan, infrastructure and electricity will increase the survival for business growth of SSEs. This finding is in line with the literature review, which indicates that microcredit is crucial for the successful establishment and growth of SSEs (Akinboyo, 2007; Pronyk et al, 2007; Anyanwu, 2014; Ogunleye, 2015). Thus, accessibility of microcredit is crucial for the successful establishment and subsequent growth of SSEs. However, it is important for the entrepreneurs to have the relevant skills and expertise required to make profitable use of such funds. In conclusion, the findings of this academic 
research indicate the need for the government of developing countries to become more proactive in the quest to improving accessibility of microcredit for the SSEs. The results also revealed the need for microfinance banks to assist beneficiaries of small loans, by proffering basic training on business planning and financial management. This will help to boost the entrepreneurs' ability to generate considerable returns on their original investments.

\section{Recommendations}

The results of this academic study indicate that microcredit is essential for the successful establishment and subsequent development of start-ups. Thus, it is advisable for the federal, state and local governments to create lending programs that will enable aspiring entrepreneurs to have more access to microcredit. Similarly, it is also recommendable for the government to enact laws and implement policies that will make it easier for small scale entrepreneurs to obtain finance necessary for the expansion of their businesses. A typical example will be the creation of government-sponsored cooperatives in the rural areas of the country. Such approach will help ensure the survival and growth of the businesses.

Secondly, the Central Bank of Nigeria should allow microfinance banks to acquire long-term capital from financial bodies like Pension and Insurance Companies. This strategy will help such institutions to give out loans at smaller interests, thereby make its services available for poor members of the society. Furthermore, such technique will also enable the microcredit institutions to increase the duration for the payment of their interest. Furthermore, the microfinance bank should obtain more funds from the informal financial market, so as to be able to bridge the gap that exist lending rate and saving deposit rate.

Lastly, the relevant stakeholders should endeavour to allow small scale entrepreneurs to have access to bigger financing windows like Strategic Partners or SMEEIS fund. However, it is advisable to institute such partnership in a way that will help ensure the services of microfinance depend primarily on social capital. This approach will enable microcredit institutions to offer more strategies and products to members of the public.

\section{References}

Aderibigbe, J. O. (2013). The Role of the Financial Sector in Poverty Reduction'. Central Bank of Nigeria Economic and Financial Review, 39(4), 1-13

Aderibigbe, J. O. (2001). The role of the financial sector in poverty reduction. Lagos: Mixon publisher.

Aguilar, V. G. (2006). Is Micro-Finance Reaching the Poor? An Overview of Poverty Targeting Methods. Retrieved from www.globalnet.org

Akinboyo, O. L. (2007). Microfinance banks: unlocking the potentials of micro-business activities of the Nigerian rural economy. CBN Bullion, 31(1), 39-51.

Akinboyo, O. L. (2007). Microfinance banks: Unlocking the potentials of micro-business activities of the Nigerian rural sector. Bullion Publication of the CBN, 31(1), 39-44. 
Akingunola R. O., Adekunle O. A., Adegbesan K. J., \& Aninkan O. O. (2013). Microfinance Banks and Entrepreneurship Development in Nigeria: A Case of Ogun State. European Journal of Business and Management, 5(28), 100-110

Anyanwu, C. M. (2014). Microfinance Institutions in Nigeria: Policy, Practice and Potentials. Being a Paper presented at the G24 Workshop on 'Constraints to Growth in Sub Saharan African', Pretorial Hotel, South Africa.

Asiama, J. P., \& Osei, V. (2007). Micro finance in Ghana: An Overview, Research Department Working Paper Bank of Ghana 07/01. Accra.

Bhatt, N., \& Shui Yan T. (1998). The Problem of Transaction Costs in Group-Based Microlending: An Institutional Perspective. Delhi: World Development.

Buckley, G. (1997). Microfinance in Africa: Is it either the Problem or the Solution? World Development report, 25(7), 1081-1091.

Central Bank of Nigeria (2005). Microfinance policy, regulatory and supervisory framework for Nigeria. A policy launched at the National Seminar to mark the United Nations International Year of Micro credit (IYMC), Abuja, 73.

Chemin, M. (2008). The Benefits of Microfinance from Bangladesh, Journal of Development Studies, 44(4), 463-484

Claessens, S., \& Tzioumis, K. (2006). Measuring firms’ access to finance, MIMEO, World Bank Report, Washington DC.

Coase, R. H. (1960). 'The Problem of Social Cost. Journal of Law and Economics, 1(1), $1-44$.

Egwuata, B. (2008). Reducing poverty through better credit delivery: The Asian Experience. CBN Bullion, 32(1), 8-16.

Fashola, B. R. (2008). Inauguration of microfinance institutions board. The punch (Friday September 19, 2008. p.17.

Hisrich, R. D., Peters, M. P., \& Shepherd, D. A (2008). Entrepreneurship. New York: Mc GrawHill.

Hosseini, S. S., Khaledi, M., Ghorbani, M., \& Brewin, D. K. (2012). An analysis of transaction cost of obtaining credits in rural Iran. Journal of Agricultural Science and Technology, 14(2), 243-256.

Hulme, D., \& Mosley, P. (1996). Finance against poverty. New York: Routledge.

Iweala, N. O. (2005). The role of government in development of microfinance in Nigeria. CBN proceedings of seminar in microfinance policy, regulatory and supervisory framework for Nigeria. 
Karlan, D., \& Zinman, J. (2006). Credit Elasticities in Less Developed Economies: Implications for Microfinance, Retrieved from www.povertyactionlab.org.

Karnani, A. (2007). Microfinance Misses its Mark. Stanford Social Innovation Review, 1(1), $1-10$.

Khan, M. A., \& Rahaman, M. A. (2007). Impacts of Microfinance on Living Standards, Empowerment, and Poverty Alleviation and Poor People: A Case Study on Microfinance in the Chittagong District of Bangladesh. Retrieved from http://www.essays.se.

Ledgerwood J. (1999). Microfinance handbook: An institutional and financial perspective, Washington, D.C World Bank.

Littlefield, E. (2005). Microfinance - Where We Are Now and Where We Are Headed, Microfinance speech given at the International Year of Microcredit and Georgetown University Conference on, Washington DC.

Mohammad, A. K., \& Mohammed, A. R. (2007). Impact of Microfinance on Living Standards, Empowerment and Poverty Alleviation of Poor People: A Case Study of Microfinance in the Chittagong District of Bangladesh, A Thesis submitted to Department of Business Administration, Umeå School of Business (USBE).

Muogbo, U. S., \& Tomola O. (2018). The Impact of Microfinance Bank on Entrepreneurship Development in Nigeria. Journal of Business and Economic Development, 3(2), 51-61.

Ndife, C. F. (2013). The Impact of Micro Credit Institutions on the Development of Small and Medium Enterprises in Anambra State, Journal of Business and Management, 14(15), 75-81.

Ojo, O. (2016). Impact of Microfinance on entrepreneurial development: The case of Nigeria. A paper presented at The International Conference on Economics and Administration, Faculty of Administration and Business, University of Bucharest, Romania ICEA-FAA Bucharest.

Olaitan, M. A. (2006). Finance for Small and Medium Scale Enterprises in Nigeria. Journal of international farm management, 3(2), 1-12

Oshitola. (2012). Microfinance Bank as a Catalyst for Entrepreneurship Development in Nigeria: An Evidence From Ogun State. An Unpublished Msc Thesis, Olabisi Onabanjo University, Ogun State, Nigeria.

Otero, M. (1999). The Evolution of Non-Governmental Organizations toward Financial Intermediation. West Hartford, CT: Kumarian Press.

Priya, M. (2006). The Effects of Microfinance Program Participation on Income and Income Inequality: Evidence from Ghana. Retrieved from http://cniss.wustl.edu/publications

Pronyk, P. Hargreaves, J., \& Murdoch J. (2007). Microfinance Programmes and Better Health: Prospects for Sub Saharan Africa. Journal of American Medical Association, 29(16), 
1925-1927.

Pronyk, P. Hargreaves, J., \& Murdoch J. (2007). Microfinance Programmes and Better Health: Prospects for Sub Saharan Africa. Journal of American Medical Association, 29(16), 1925-1927.

Robinson, M. S. (2001). The microfinance revolution. The World Bank Review, 20(1), 1463-1470.

Roodman, D. (2009). What do we Really Know about Microfinance? Retrieved from http://blogs.cgdev.org.

Rosenberg, R., (2006). Microcredit interest rates. In Robinson, M. (2013). The microfinance revolution: Sustainable finance for the poor. Vol. 1. Washington D.C.: World Bank.

Sachs, J. (2009). Is Microfinance the Solution to Poverty? Retrieved from http://www.kiva.org

Simanowitz, A., \& Brody, A. (2004). Realizing the Potential of Microfinance. Insight, 51(1), 1-2.

Stiglitz J. (1990). Peer monitoring and Credit Markets. The World Bank economic Review, 4(1), 351-366.

Sulistya, G. A., \& Darwanto, A. (2016). Transaction cost of micro and small enterprises financing. Economic Journal of Emerging Markets, 8(2), 171-186.

United Nations Capital Development fund [UNCDF] (2009). Enabling Poor Rural People to Overcome Poverty in Ghana. United Nations, New York.

Wehrell, R., Campbell, M., Cunningham, G., \& Lee, N., (2002). The Atlantic Micro-credit Socio -Economic Impact Study Final Report. Steering Committee to Coordinate Research on Microcredit in Atlantic Canada.

Williamson, O. E. (1985). The economic institutions of capitalism: firms, markets, relations, contracting. New York: The Free Press A Division of Macmillan, Inc.

\section{Copyright}

Copyright for this article is retained by the author(s), with first publication rights granted to the journal.

This is an open-access article distributed under the terms and conditions of the Creative Commons Attribution license (http://creativecommons.org/licenses/by/4.0/). 